\title{
SYNCHRONIZATION OF POWER FROM GRID AND PV SYSTEM WITH MPPT BASED ON INCREMENTAL CONDUCTANCE TECHNIQUE
}

\author{
A.Shanmughapriya ${ }^{1}$, P.Saranya ${ }^{2}$, S. Angeline Sreeja ${ }^{3}$ \\ ${ }^{I}$ M.E, Power Systems Engineering, Kalaignar Karunanidhi Institute of Technology, Tamilnadu, India \\ ${ }^{2}$ M.E, Power Systems Engineering, Kalaignar Karunanidhi Institute of Technology, Tamilnadu, India \\ ${ }^{3}$ M.E, Power Systems Engineering, Kalaignar Karunanidhi Institute of Technology, Tamilnadu, India
}

\begin{abstract}
The optimization of energy consumption, with consequent costs reduction is one of the main challenges in present and future smart grids. As increasing power consumption is becoming a huge problem everywhere, solar energy has been highlighted recently. In renewable energies solar energy is the one of the most commonly used form of energy hence in our paper it has been highlighted. Many companies and research centers study this new sustainable energy and various products have appeared to the public. However, this kind of researches concentrates on the elemental technologies, and now a management system is needed to manage these technologies to maximize energy efficiency. In this paper the proposal is that the system management of hybrid system to load. It has been done by using the MATLAB software. In this paper Incremental Conductance based MPPT for photovoltaic system is done for the development of solar technologies and power from both EB as well as solar are managed efficiently to get the optimum usage of power.
\end{abstract}

Keywords: MPPT, Optimal power management.

\section{INTRODUCTION}

Renewable energy is the energy which comes from natural resources such as sunlight, wind, tides and geothermal heat which are naturally replenished. Renewable sources of energy acquire growing importance due to its enormous consumption and exhaustion of fossil fuel. Solar energy is the energy extracted from the rays issued from the sun in the form of heat. This energy is essential for all life on earth. It is a renewable resource that is clean, economical, and less pollution compared to other resource of energy. Energy supplied by the sun in one hour is equal to the amount of energy required by human in one year. Photovoltaic cell generates electricity from the PV panel works under the phenomenon of photoelectric effect. A solar cell may operate over a wide range of voltages (V) and current (I). By increasing the resistive load on a Irradiated cell continuously from zero (a short circuit) to a very high value (an open circuit) one can determine the maximum power point, the point that maximizes $\mathrm{V}^{*} \mathrm{I}$

That is, the load for which the cell can deliver maximum electrical power at that level of irradiation. The optimum operating point changes with solar irradiation and cell temperature. This paper deals with 'INCREMENTAL CONDUCTANCE' MPPT algorithm method due to its simple approach [1] to find the maximum power point of the solar panel In the incremental conductance method, the controller measures incremental changes in array current and voltage to predict the effect of a voltage change. This method requires more computation in the controller, but can track changing conditions more rapidly than the previous method. The incremental conductance method computes the maximum power point by comparison of the incremental $(\Delta \mathrm{I} / \Delta \mathrm{V}) \mathrm{TO}$ THE ARRAY CONDUCTANCE (i/v). When these two are the same $(\mathrm{I} / \mathrm{V}=\Delta \mathrm{I} / \Delta \mathrm{V})$, the output voltage is the MPP voltage. The controller maintains this voltage until the irradiation changes and the process is repeated. The expected output from solar is obtained then it can be managed with the help of power from EB. The EB power is synchronized with the solar power for individual consumers so that when there is no solar we can take it from EB. In residential areas, energy storage is practically synonymous with batteries[2].In practice, the battery is not ideal and has some physical properties as analyzed in[3][4].In order to protect the battery from over charge and over discharge a controller is needed to regulate the charging and discharging process[5].

\section{SYSTEM MODEL}

The photovoltaic cell is used to generate solar energy in which the maximum power is obtained by tracking. The PV array terminal voltage is always adjusted according to the MPP voltage in incremental conductance method. The block diagram for MPPT is shown in Fig-2[6][7]. 


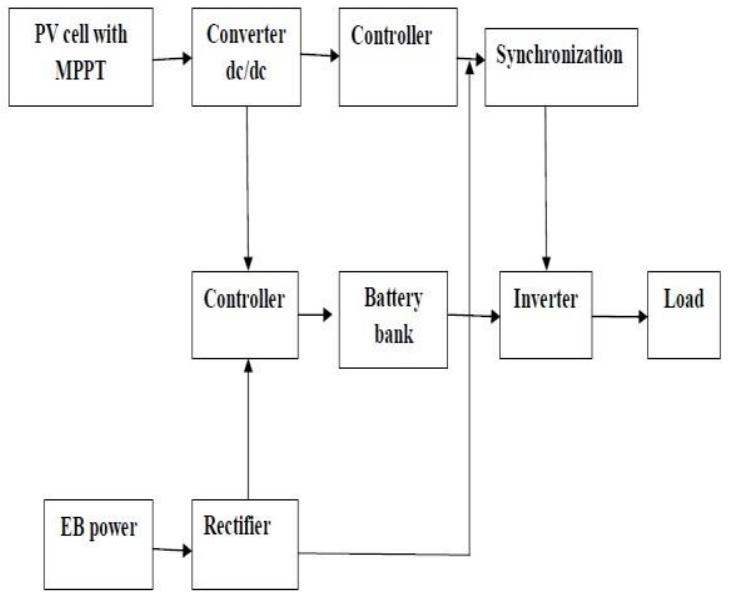

Fig- 1 block diagram

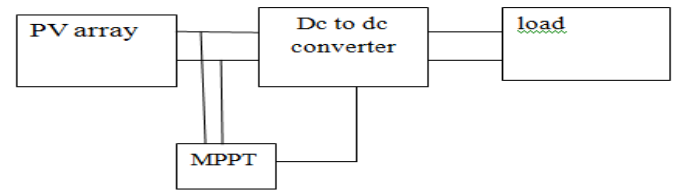

Fig- 2 Photovoltaic blocks

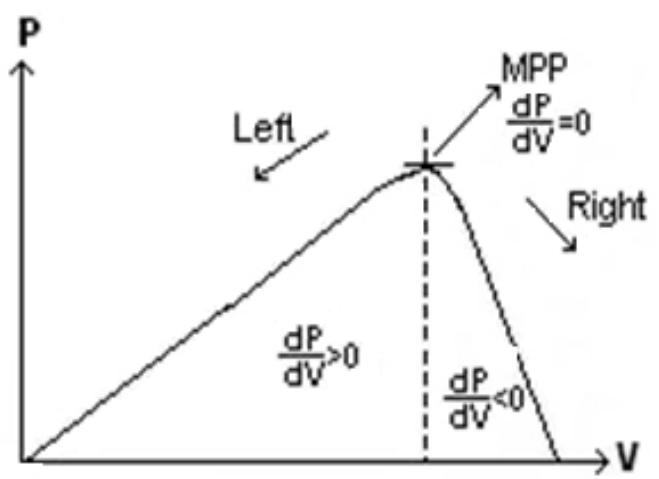

Fig-3 P-V curve of the solar module

Fig-3 shows the P-V curve of solar module. At MPP the power curve is zero. It is decreasing on the right hand side and increasing on the left hand side of MPP.The basic equations are[8], At MPP, $\partial \mathrm{p} / \partial \mathrm{v}=0$

The above equation could be written in terms of array voltage $\mathrm{v}$ and array current $\mathrm{I}$ as, $\partial \mathrm{I} / \partial \mathrm{v}=-\mathrm{I} / \mathrm{V}$

The PWM control signal to the dc to dc converter [9] is regulated by MPPT until the condition

$\partial \mathrm{I} / \partial \mathrm{v}+(\mathrm{I} / \mathrm{V})=0$ is satisfied. Converter converts variable voltage level to constant voltage level. Controller decides which power to charge the battery and also decides the amount of power given to the load by the two sources. Synchronization is done in such a way that if the load demand is equal to the available solar power, then the solar energy is entirely used for consumption. If the load demand is greater than the available solar power energy for consumption is taken from EB. If the power from the EB is not available the required power is taken from battery. If both the power from solar and EB are not available the required power is taken from the battery.

\section{SIMULATION}

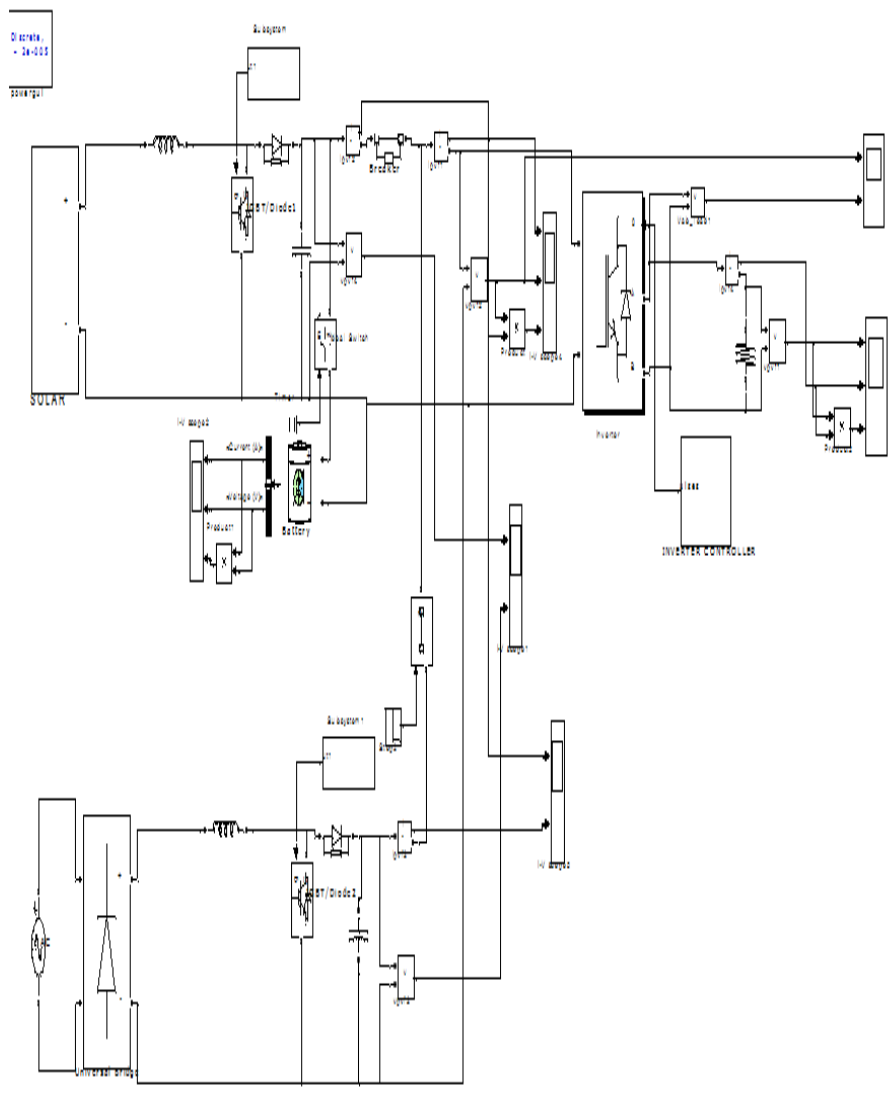

Fig- 4 over all simulation diagram

Simulink is a software package for modeling, simulating, and analyzing dynamical systems. It supports linear and nonlinear systems, modeled in continuous time, sample time, or a hybrid of the two. Since MATLAB and Simulink are integrated, the simulation, analyzation, and the revision of models are done in either environment at any point. Figure 4 shows the overall simulation diagram. The simulation model for MPPT is shown in Fig-5 


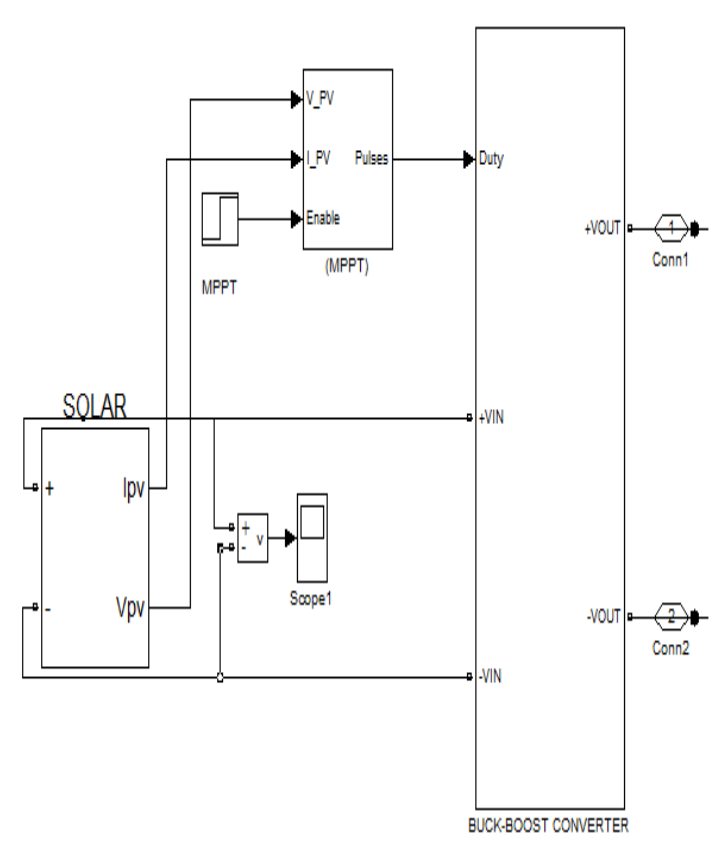

Fig- 5 simulation diagram for MPPT

The photovoltaic model circuit is implemented with a help of MATLAB/SIMULINK.

\section{SIMULATION RESULT}

The output of the PV array depends on temperature and irradiation. In this paper the temperature an irradiation is designed as 273.15 degree Celsius and $200 \mathrm{w} / \mathrm{m} 2$ respectively. Output of the solar panel is $163 \mathrm{w}$. The output current and voltage is $2.45 \mathrm{~A}$ and $88.5 \mathrm{v}$ respectively.

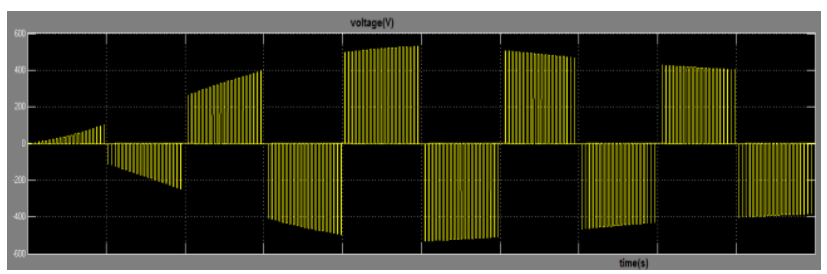

Fig-6 synchronized voltage waveform

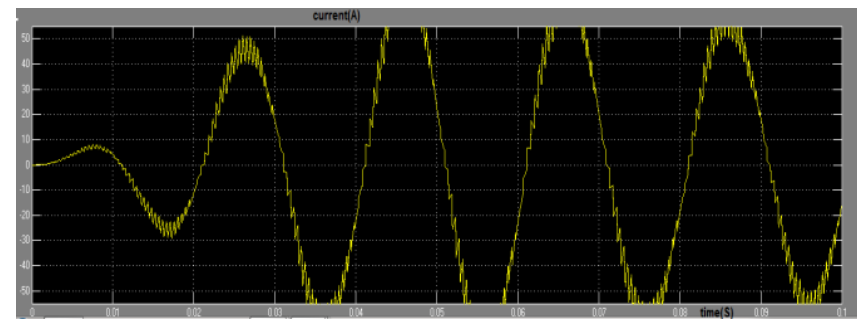

Fig-7 synchronized current waveform

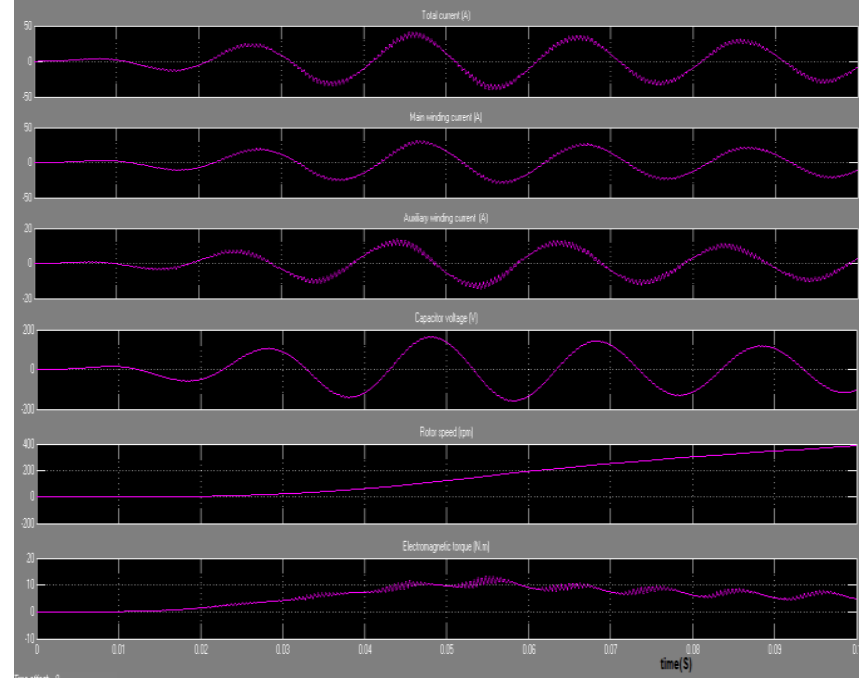

Fig-8 current, voltage waveforms of induction motor as a load

When the generated power from the PV array is not enough then the power from the EB is synchronized with the solar output. The synchronized voltage and current waveform is shown in fig- 6 and fig- 7. In this paper the output power from the solar array is considered as $163 \mathrm{w}$. When the load is increased above this level the remaining power is synchronized with it from the EB.The variation of solar alone and synchronized voltage is shown in the same output i.e., up to $0.02 \mathrm{~s}$ the solar output is connected to the load after that the synchronized power is connected to the load. Fig- 8 shows the induction motor as considered as a load.

\section{CONCLUSIONS}

In this paper the simple MPPT method is included to increase the efficiency of the output because this method needs only the calculation of the conductance. So that the output power from the array is increased and the power taken from the EB is decreased. This method reduces the amount of power taken from the EB so that the tariff amount is low compared to the normal method. The drawback of this method is the synchronization of power is difficult task. The future development can also be made by the excess power generated by this method is synchronized with the grid.

\section{REFERENCES}

[1]. Hussein,K.H.,Mutra,I.Hoshino,T.,Osakada.M.,’Maximum photovoltaic power tracking: an algorithm for rapidly changing atmospheric conditions",IEEE Proceedings of Generation, Transmission and Distribution,vol.142,No.1,1995. [2]. Optimal Power Management of Residential Customers in the Smart Grid.Yuanxiong Guo,Student Member,IEEE,Miao Pan,Student Member,IEEE, and Yuguang Fang Fellow,IEEE IEEE TRANSACTIONS ON PARALLEL AND DISTRIBUTED SYSTEMS, VOL 23,no.X,XXXXXXX 2012. 
[3]. A.Kansal,J.Hsu,S.Zahedi, and M.B.Srivastava, "Power Management in Energy Harvesting Sensor

Networks,"ACM Trans.Embedded Computing Systems, vol.6, p.32, Sept.2007.

[4]. R.Urgaonkar, B.Urgaonkary, M.J.Neely, and sivasubramaniam, "Optimal Power Cost Management Using Stored Energy in Data Centres,"Proc.ACM Int'1Conf.Measurement and Modeling of Computer Systems (SIGMETRICS'11) June2011.

[5]. "how a PV System Works,"Florida Solar Energy enter, http: // www.fsec.ucf.edu / en / consumer / sola_electricity/basics/h ow_pv_system_works.htm.20 2 .

6]. E.Koutroulis, ET. AL,"Development of a Microcontroller based Photovoltaic maximum power tracking control system", IEEE Trans.On power Electron, vol.16, no.1, PP.46-54, 2001.

[7]. P.Ribeiro, B. Johnson M.Crow, A.Arsoyand Y.Liu, "Energy Storage System for Advanced Power Applications, "Proc. IEEE, vol.89, no.12, pp.1744-1756, Dec .2001

[8]. Incremental Conductance Based Maximum Power Point Tracking (MPPT) for Photovoltaic System. M. Lokana dham, K.Vijaya Bhaskar / International Journal of Engineering Research and Applications (IJERA) ISSN: 2248-9622 www.ijera.com Vol.2, issue 2, Mar-Apr 2012, pp.1420-1424

[9]. Maximum power point tracking techniques for solar water pumping systems. A.Daoud and A.Midoun. Revuedes Energies Renovelabes Vol.13 (2010)497-507 [10]. Modelling and Circuit /based Simulaton of Photovoltaic Arrays M.G. Villalva,J. R.Gazoli,E.Ruppert Journal of Power Electronics, 2009.

\section{BIOGRAPHIES}

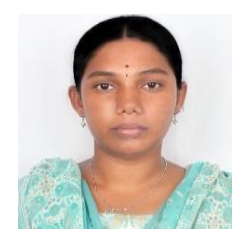

Ms.A.Shanmughapriya was born on $22^{\text {nd }}$ December 1991 in Coimbatore. She has completed her UG degree B.E Electrical and Electronics Engineering in SNS College of Engineering during the year 2009 to 2013 under Anna University, Chennai. She is now currently pursuing her PG course specialized in Power Systems Engineering in Kalaignar Karunanidhi Institute of Technology under Anna University Chennai. Her main aim is to complete her doctorate degree within 5years.

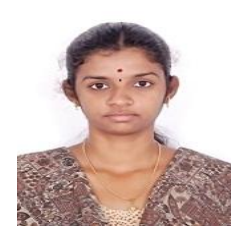

Ms.P.Saranya was born on $24^{\text {th }}$ September 1991 in Coimbatore. She has completed her UG degree B.E Electrical and Electronics Engineering in SNS College of Engineering during the year 2009 to 2013 under Anna University, Chennai. She is now currently pursuing her PG course specialized in Power Systems Engineering in Kalaignar Karunanidhi Institute of Technology under Anna University Chennai. Her main aim is to start an organization for the needy people and to help others then to get a doctorate degree.

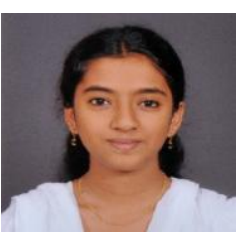

Ms.S.Angeline Sreeja was born on $4^{\text {th }}$ January 1992 in Coimbatore. She has completed her UG degree B.E Electrical and Electronics Engineering in SNS College of Engineering during the year 2009 to 2013 under Anna University, Chennai. She is now currently pursuing her PG course specialized in Power Systems Engineering in Kalaignar Karunanidhi Institute of Technology under Anna University Chennai. Her main aim is to complete her doctorate degree within 5years and to publish more papers. 